\title{
(5)
}

AL-DZIKRA

Jurnal Studi Ilmu Al-Qur'an Dan Al-Hadits

http://ejournal.radenintan.ac.id/index.php/al-dzikra

Volume 11, No. 2, Desember Tahun 2017, Halaman 239 - 260

DOI://dx.doi.org/10.24042/al-dzikra.v11i2.4520

\section{ITSMUN PERSPEKTIF TAFSIR ISYARI}

\begin{tabular}{c}
\hline Nur Yamin \\
UIN Raden Intan Lampung \\
yamin_nur@gmail.com \\
\hline
\end{tabular}

\section{Abstrak}

Itsmun adalah istilah yang digunakan dalam al-Qur'an yang dipakai sebagai istilah dosa, yang mempunyai makna perbuatanperbuatan yang menghambat tercapainya pahala. Itsmun dengan kata lain adalah sebutan atas tindakan yang menghambat tercapainya (terwujudnya) kebaikan. Itsmun di dalam al-Qur'an digunakan untuk menyebutkan sebuah pelanggaran yang memiliki efek negatif terhadap diri sendiri dan masyarakat. Maka itsmun dikatakan dosa apabila perbuatan tersebut merupakan perbuatan yang telah merugikan diri sendiri dan orang lain. Itsmun dalam pemaknaannya banyak disampaikan oleh kalangan sufi, khususnya dalam menafsirkan ayat-ayat yang terkait dengan Itsmun. Imam Al-Alusi merupakan tokoh mufassir klasik yang ternama, khususnya pada kalangan ulama tasawuf yang menggunakan tafsir aliran sufistik isyari. Pemikiran Al-Alusi dalam tafsir Rûh al-Ma'ânî tidak terlepas dari kiprah beliau dalam konteks idiologi beliau mengenai prihal aqidah. Adapun mengenai penafsiran beliau tentang ayat-ayat itsmun, Al-Alusi tidak terlepas dari kesufiannya dalam pemikirannya. Penelitian ini termasuk dalam jenis penelitian pustaka (library research) dengan menggunakan metode deskriptif analitis yang pokok kajiannya pada kitab tafsir Rûh al-Ma'ânî. Dengan menggunakan metode tersebut, peneliti mendapati secara umum Al-Alusi menyatakan bahwa itsmun 
adalah orang yang banyak dosa, orang kafir, kebohongan, serta dalam setiap ayat mengandung makna yang melawan Allah dan Rasul, serta memiliki efek negatif terhadap diri sendiri dan orang lain. Adapun solusi yang diberikan terhadap orang yang berbuat dosa yaitu dengan cara bertaubat kembali kepada petunjuk Allah dan menjauhi semua larangannya serta tidak mengulangi perbuatan dosa lagi.

Kata Kunci: Itsmun, Tafsir Isyari, Imam al-Alusi

\section{A. Pendahuluan}

Al-Qur'an adalah kalam Allah swt. yang tiada tandingannya. Ia merupakan mu'jizat yang diturunkan kepada Nabi Muhammad saw. yang dinyatakan sebagai penutup para Nabi dan Rasul, dengan perantara malaikat Jibril, diriwayatkan secara mutawatir, ${ }^{1}$ dimulai dari surat al-Fätihah dan kemudian ditut up dengan surat an-Nās. ${ }^{2}$ Al-Qur'an memperkenalkan dirinya dengan berbagai ciri dan sifat. Salah satunya adalah jaminan pemeliharaan dari Allah swt. atas keotentikannya.

Allah swt. berfirman dalam al-Qur'an surah al-Hijr 15: 9.

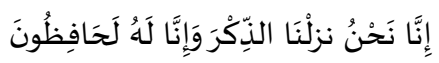

"Sesungguhnya Kami-lah yang menurunkan Al-Quran, dan Sesungguhnya kami benar-benar memeliharanya". ${ }^{3}$

Dengan jaminan ayat di atas, maka setiap muslim percaya bahwa apa yang di baca dan didengarnya sebagai al-Qur'an tidak

${ }^{1}$ Diriwayatkan oleh sejumlah perawi yang secara tradisi tidak mungkin mereka sepakat berdusta dari sejumlah perawi yang sepadan dari awal sanad sampai akhirnya, dengan syarat jumlāh itu tidak berkurang pada setiap tingkatan sanadnya. Lihat Muhammad 'Ajaj al-Khatib, Ushul al-Hadits, terj, cet. III (Jakarta: Gaya Media Pratama, 2003), hlm. 271. Lihat juga Syaikh Manna' alQatthan, Pengantar Studi Ilmu Hadits, Mifdhol 'Abdurrahman, terj, (Jakarta: Pustaka al-Kautsar, 2005), hlm. 110

2 Muhammad Ali ash-Shābuni, Pengantar Studi al-Qur'an (terj), (Bandung: Al-Ma'rif, 1984), hlm. 18

Departemen Agama RI, al-Qur'an dan Terjemahannya, (Depok: Cahaya Qur'an, 2008), hlm. 87 
pernah berbeda sedikitpun dengan apa yang pernah di baca oleh para sahabat Nabi Muhammad saw. ${ }^{4}$

Dengan definisi ini, bahwa al-Qur'an merupakn firman Allah swt. yang diturunkan kepada Nabi Muhammad saw, selain pada itu tidak disebut al-Qur'an. Taurat yang diturunkan kepada Nabi Musa, atau Injil yang diturunkan kepada Nabi Isa. Demikian juga, kata-kata Allah swt. yang dikirim kepada Nabi Muhammad saw., mereka yang membacanya tidak dianggap sebagai ibadah, seperti Hadits Qudsi, tidak pula di namakan al-Qur'an. ${ }^{5}$ Sedangkan dari pendapat lain mengatakan bahwa al-Qur'an merupakan firman Allah swt. yang tidak tertandingi. Dia adalah mukjizat yang diturunkan kepada Nabi Muhammad saw. sebagai penutup bagi para Nabi dan Rasul, melalui perantara malaikat Jibril, yang di riwayatkan secara mutawatir, yang di mulai dari alFatihah dan di tutup oleh an-Nas. ${ }^{6}$

Menarik sebuah pendapat Manna al-Qatthan seperti dikutip oleh Badri Khaeruman menyatakan bahwa satu surat dari alQur'an merupakan keajaiban yang dibutuhkan oleh orang lain dalam ikatan kata, satu kata di tempat adalah ikatan kalimat, dan kalimat di tempat adalah mukjizat dalam jalinan surat. ${ }^{7}$ Sehingga reputasi al-Qur'an tidak hanya terletak pada makna literalnya saja melainkan dari segi bahasanya juga.

Keistimewaan al-Qur'an adalah suatu kegunaan yang berbeda mengenai satu masalah. Sehingga dalam ilmu-ilmu alQur'an, muncul istilah taraduf (sinonimitas) yang telah melahirkan dua kelompok. Yang mana kelompok pertama mengakui keberadaan taraduf dan kelompok kedua tidak mengakui adanya taraduf, yang berpendapat bahwa setiap kata di dalam al-Qur'an memiliki wilayah dan makna masing-masing, dan memiliki kelebihan tersendiri. Selain itu, al-Qur'an tidak hanya dipelajari dari pemilihan bentuk struktur editorial dan pemilihan

${ }^{4}$ Muhammad Quraish Shihab, Membumikan Al-Qur'an: Fungsi dan Peran Wahyu Dalam Kehidupan Masyarakat, (Bandung: Mizan, 1992), hlm. 21

${ }^{5}$ Muhammad Quraish Shihab, Membumikan Al-Qur'an, hlm. 21

${ }^{6}$ Muhammad Ali ash-Shabuni, Pengantar Studi al-Qur'an, terj. hlm. 18

7 Badri Khairuman, Sejarah Perkembangan Tafsir Al-Qur'an, (Bandung: CV Pustaka Setia, 2004), hlm. 17 
kosa kata. Tetapi ada juga konten di dalamnya baik tersurat maupun tersirat dan bahkan untuk kesan yang disebabkan di dalamnya.

Banyaknya keistimewaan yang mulai muncul ketika alQur'an menggunakan suatu istilah yang berbeda mengenai satu masalah. Sebagai contoh, dosa, ternyata al-Qur'an menggunakan istilah dosa lebih dari satu, yang menggunakan istilah dosa, seperti itsmun, dzanb, junah, khati'ah, dan jarm. Dengan demikian dari sejumlah istilah yang digunakan oleh al-Qur'an istilah-istilah tersebut memiliki karakter (perbedaan) tersendiri dibandingkan dengan istilah lainnya. Perbedaan yang muncul dalam istilah ini terletak pada makna yang lebih kepada dosa dan mengandung masalah yang merugikan atau menghilangkan akal.

Itsmun adalah suatu kata yang terdiri dari huruf alif, $\underline{t}$ sa'dan mim yang menunjukkan arti البطء (asal) dan التأخر yang lambat / panjang dan berakhir. Karena itu al-itsmu bisa mempunyai arti jauh dari sebuah kebaikan atau akhir. Oleh sebab itu al-itsmu bisa berarti jauh/lambat dari kebaikan atau bisa diartikan mengakhirkan kebaikan. ${ }^{8}$

Dari penjelasan di atas, penelitian ini menggunakan metode analisis deskriptif dengan berfokus pada studi kepustakaan (Library Riseant) dengan obyek utama kitab Rûh al-Ma'anî yang dikarang oleh Imam al-Alusi. Dalam penelitian ini, penulis mengkaji secara focus kata Itsmun dalam tafsir Ruh al-Ma'ani. Kitab tafsir Ruh al-Ma'ani mulai di tulis pada tanggal 16 Sya'ban $1252 \mathrm{H}$, yang didahului oleh mimpi bertemu langit dan bumi. Tulisan ini berlangsung selama lebih dari 10 tahun, tafsir Ruh alMa'ani berisi berbagai pandangan baik dari para ulama khalaf dan salaf juga menjelaskan pendapat interpretasi sebelumnya, ${ }^{9}$ misalnya Ibn Aliyah, Ibnu Hayyan, al-Kassyaf, Abi al-Su'ud, alBaidhowi dan al-Fahr al-Rozi.

Imam Al-Alusi adalah seorang ulama tafsir sufi yang sangat terkenal dimasanya. Beliau merupakan keturunan dari seorang ayah yang bernama Baharuddin al-Alusi yang merupakan

${ }^{8}$ Abu al-Husain Ahmad Ibn Faris Zakariyya, Mu'jam Maqayis alLugah, Juz. II, (Cairo: Dar al-Hadis, 1998), hlm. 60

9 AS Hornbay, Oxford Advanced Leavers Dictionary of Current English, (tp: Oxford University Press, 1963), hlm. 533 
keturunan dari al-Hasan (Ibn Ali bin Abi Thalib). Beliau lahir di Bagdad pada $1217 \mathrm{H} / 1802 \mathrm{M}$, dan wafat pada tanggal 25 Dzulqa'dah 1270 H/1854 M. ketika berusia 53 tahun. ${ }^{10}$

Maka dengan hal tersebut peneliti lebih menekankan pada ayat-ayat yang mengandung atau terdapat kata itsmun disetiap ayat dan surat, untuk mengetahui bagaimana penafsiran kata itsmun dalam tafsir Ruh al-Ma'anî sekaligus untuk mengetahui pandangan Al-Alusi terhadap kandungan ayat yang menggunakan

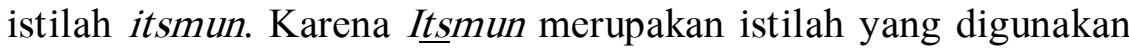
atau dipakai al-Qur'an untuk menyebut kata dosa. Pembahasan yang perlu diteliti dan di kaji dalam rangka memberikan pemahaman yang utuh kepada masyarakat umum (muslim) melalui pandangan imam Al-Alusi dalam tafsir Ruh al-Ma'anî, yakni yang beraliran sufi, yang mana perbuatan dosa sangat di perdebatkan di kalangan ulama tasawuf, karena memang orangorang tasawuf atau sufi sangat terkenal dengan kezuhudannya, yang mengutamakan akhirat dibanding duniawinya.

\section{B. Pengertian Dosa dan Macam-Macam Dosa}

I $\underline{t}$ smun adalah suatu kata yang terdiri dari huruf alif, $\underline{t}$ a ${ }^{\prime}$ dan mim yang menunjukkan arti البطء (asal) dan التأخر yang lambat / panjang dan berakhir. Karena itu al-itsmu bisa mempunyai arti jauh dari sebuah kebaikan atau akhir. Oleh sebab itu al-itsmu bisa berarti jauh/lambat dari kebaikan atau bisa diartikan mengakhirkan kebaikan. ${ }^{11}$

Mengutip sebuah bahasa yang terdapat di kamus lisan al'Arab dinyatakan bahwa itsmun adalah melakukan sesuatu hal yang dianggap tidak halal (haram). Bentuk turunan dari kata ini adalah أثنّم yakni yang bermakna bertaubat dari dosa dan

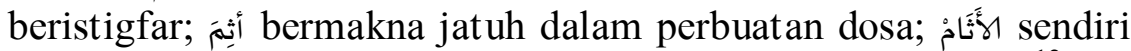
berarti bermakna balasan dari dosa, yakni al- 'uqubah (siksa). ${ }^{12}$

${ }^{10}$ Muhammad Husain al-Dzahabi, Al-Tafsir Wa al-Mufassirun, Juz I. (Dar al-Ma'arif, t. t, 1976), hlm. 35

11 Abu al-Husain Ahmad Ibn Faris Zakariyya, Mu'jam Maqayis alLugah, hlm. 60

${ }^{12}$ Ibnu Manzur, Lisan al-'Arab, Juz 1, (Cairo: Dar al-Hadis, 2001), hlm. 79 
Definisi dosa (itsmun) menurut bahasa adalah melakukan tindakan yang melanggar hukum dan tidak dihalalkan. ${ }^{13}$ Dosa dalam bahasa Arab disebut dengan itsmun dan 'ishyân, dosa dengan memarahi ini berarti berbalik atau salah dan lalai, menentang perintah atau larangan Allah swt., dengan melakukan tindakan yang ada di mata sang Pencipta tidak baik dan tidak layak. Karena ia memiliki unsur merusak atau mafsadah sehingga hal ini dilarang, atau tidak melakukan dan meninggalkan suatu pekerjaan yang wajib dan harus (ditinggalkan) karena di belakang larangan ada manfaatnya. Dengan demikian, tindakan dosa itu bertentangan dengan konsep ubudiyah (kepatuhan dan pengabdian). Dosa (dalam pengertian umum) tidak sesederhana memahami dosa itu sendiri, hal tersebut dianggap dosa (dengan nama-nama tertentu) setelah melakukan suatu tindakan dengan hukum tertentu yang melekat, serta pengampunan dalam dosa itu. $^{14}$

Mengutip pendapat Al-Ragib al-Asfahani, yang disebut itsmun adalah nama tindakan yang telah menghambat datangnya jasa kebajikan. Dengan kata lain, itsmun adalah istilah untuk tindakan yang menghambat terealisasinya kebaikan. Beliau juga menyatakan bahwa itsmun itu lebih umum. ${ }^{15}$ Beliau juga memberikan pernyataan menarik mengenai hal ini, yakni bahwa setiap itsmun itu merupakan junāh. ${ }^{16}$ Hal senada juga diungkapkan oleh 'Abd al-Rauf al-Misri bahwa kata junāh di dalam al-Qur' an memiliki banyak makna di antaranya adalah alitsm, al-kharaj, al-mani' (larangan) dan al-tib'ah (tanggung jawab). ${ }^{17}$

Menurut terminologi, dosa adalah segala sesuatu yang bertentangan dengan syariat dan perintah Allah swt. baik yang

${ }^{13}$ Ibnu Mandzur, Lisan Arab, hlm. 74

14 Halimi Zuhdy, Derai Dosa, Derasnya Ampunan Sang Penguasa Semesta (Membincang Dosa dan Pengampunan dalam Perspektif Islam), Jurnal, Universitas Islam Negeri (UIN) Maulana Malik Ibrahim Malang.

15 Ar-Ragib al-Asfihani, Mu'jam Mufradat Alfad al-Qur'an, (Beirut: Dar al-Fikr, t.th), hlm. 6

${ }^{16}$ Ar-Ragib al-Asfihani, Mu'jam Mufradat Alfad al-Qur'an, hlm. 98

17 'Abd Rauf Al-Misri, Mu'jam al-Qur'an wahuwa Qamus mufradaat al-Qur'an wa Gharibuhu, (Cairo: Maktabah al-Hijazi, 1948), juz 1, hlm. 169 
berkaitan dengan melakukan sesuatu ataupun meninggalkannya. ${ }^{18}$ TM. Hasbi Ash-Shiddieqy merumuskan dosa sebagai pelanggaran terhadap sesuatu ketentuan Tuhan. Ketentuan Tuhan di sini merupakan ketentuan Tuhan yang hukumnya bersifat wajib untuk dikerjakan atau wajib untuk ditinggalkan. Jadi bukan ketentuanketentuan Tuhan yang hukumnya hanya bersifat sunah, makruh atau mubah. ${ }^{19}$

Dalam al-Qur'an term dosa disebut dengan beragam kata yang kesemuanya; menurut sebuah pandangan yang umum, memiliki wilayah pengertian dan makna yang hampir sama, di antara terma-terma tersebut: Khati'ah, zanbun, Itsmun, Fisq, Isyan, 'Utwun dan Fasad. ${ }^{20}$ Istilah dosa yang kita gunakan merupakan sebuah istilah yang berasal dari kalangan agama Hindu, dan telah lazim digunakan oleh umat Islam yang berbahasa Indonesia sebagai bentuk pelanggaran hukum, baik itu hukum Tuhan (Agama), hukum adat, maupun hukum negara. ${ }^{21}$

Dosa dalam ajaran Islam dapat dikelompokkan menjadi tiga yaitu:

1. dosa besar yang tidak terampuni;

2. dosa besar yang masih bisa diampuni;

3. dosa kecil yang terhapus karena rajin ibadah atau karena banyak berbuat kebajikan. ${ }^{22}$

Menurut pendapat Imam Ghazali, beliau mengatakan bahwa dosa menurut sifat dasarnya dapat dibagi atas tiga bagian. Pertama yang menyangkut dengan sifat manusia itu sendiri dan terdiri atas empat sifat, yaitu sifat rububiyah, syaithaniyah, bahimiyah dan subu'iyah. Kedua yang menyangkut dengan obyeknya dapat pula dibagi atas tiga, yaitu dosa antara manusia terhadap Allah swt., dosa yang menyangkut dengan hak-hak

18 Imam Al-Ghazali, Rahasia Taubat, terj. Muhammad Baqir, (Bandung: Mizan Media Utama, 2003), hlm. 61

19 T.M. Hasbi Ash-Shiddieqy, Al-Islam I, (Semarang: PT Pustaka Rizki Putra, 2001), hlm. 468

${ }^{20}$ Ali Abdullah Fattah Thabbarah, Dosa Dalam Pandangan Islam, cet. Ke-III, (Bandung: Risalah Gusti, 1986), hlm. 34

${ }^{21}$ Tim Penulis, Ensklopedi Islam Indonesia, (Jakarta: Anggota IKAPI, 2002), hlm. 263

${ }^{22}$ Hasbullah Bakry, Pedoman Islam di Indonesia, (Jakarta: UI Press, 1988), hlm. 29 
masyarakat dan lingkungan, dan dosa terhadap diri manusia itu sendiri. Dan ketiga dosa yang ditinjau dari segi bahaya dan madaratnya yaitu terdiri atas dua, dosa kecil dan dosa besar. ${ }^{23}$

Para ulama pada umumnya telah menyetujui pembagian dosa atas dasar besar dan kecil. Dosa besar mengandung bahaya yang lebih besar, dan dosa-dosa kecil membawa lebih sedikit bahaya dan madharatnya.

Terdapat lima istilah dosa dalam al-Qur'an dengan menggunakan beragam lafad, termasuk diantaranya itsmun, khati'ah, jarmun, zanbun dan junah. Berikut ini adalah ruang lingkup dan tingkat makna setiap kata.

\section{It $\underline{\text { șmun }}$}

Definisi bahasa ini ditemukan dalam ruang lingkup makna kata itsmun, yang merupakan tindakan yang jauh dari pahala, menghambat datangnya kebaikan dan memiliki efek negatif. Kata itsmun memiliki sense yang dikaitkan dengan sesuatu yang mengganggu hati, malu dilihat oleh orang lain dan memiliki efek negatif. Kata ini dalam al-Qur'an disebutkan 48 kali dengan berbagai bentuk turunan.

Bentuk kata yang paling umum disebutkan adalah itsmun 35 kali, sisanya ditetapkan sebagai آثمين, آثما, أثما, اثثيم. Tiga puluh tujuh ayat yang mengandung kata itsmun termasuk dalam surah Madaniyyah, 11 ayat sisanya termasuk dalam surah Makkiyah. ${ }^{24}$ Ini menunjukkan bahwa kata Itssmun lebih lazim di Madinah di mana Islam telah berkembang dan menghadapi berbagai masalah hukum. Kata ini selalu digunakan dalam bentuk tunggal (mufrad). Jika itu dalam bentuk jamak, maka sering menggunakan bentuk isim fail (subjek) yaitu atsimin, bukan sebagai isim (kata benda). Tampaknya, ini menunjukkan bahwa kata Itsmun merupakan jenis dosa yang jelas dan tunggal untuk setiap ayat.

Contoh surat al-Baqarah: 206

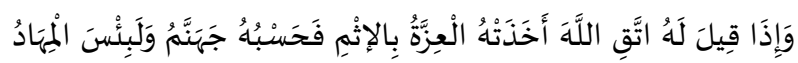

${ }^{23}$ Al-Ghazali, Rahasia Taubat, (terj), hlm. 62-65

${ }^{24}$ Muhammad Fu'ad 'Abd al-Baqi, al-Mu'jam al-Mufahras li Alfadz Al-qur'an Al-Karim, (Cairo: Dar al-Kutub al-Mishriyah, 1364), hlm. 40-42 
"Dan apabila dikatakan kepadanya: "Bertakwalah kepada Allah", bangkitlah kesombongannya yang menyebabkannya berbuat dosa. Maka cukuplah (balasannya) neraka Jahannam. Dan sungguh neraka Jahannam itu tempat tinggal yang seburuk-buruknya."

Dalam surat al-Baqarah: 173:

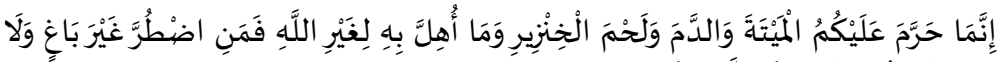

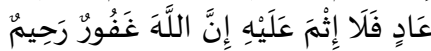

"Sesungguhnya Allah hanya mengharamkan bagimu bangkai, darah, daging babi, dan binatang yang (ketika disembelih) disebut (nama) selain Allah. tetapi Barangsiapa dalam Keadaan terpaksa (memakannya) sedang Dia tidak menginginkannya dan tidak (pula) melampaui batas, Maka tidak ada dosa baginya. Sesungguhnya Allah Maha Pengampun lagi Maha Penyayang."

\section{Khati'ah}

Istilah dosa yang lain digunakan al-Qur'an adalah kata khati'ah, kata ini berasal dari kata khata'a. Kata ini beserta turunannya disebutkan di dalam al-Qur'an sebanyak 22 kali, ${ }^{25} 15$ kata berada di dalam surah Makkiyyah dan sisanya tujuh kata berada di dalam surah Madaniyyah. Dari sisi bahasa, setiap kata yang tersusun dari huruf kha', ta' dan huruf mu'tal dan mahmuz (WaW atau hamzah) menunjukkan الشئ تعدى yakni melampaui sesuatu. Kata khata'a adalah antonim dari kata as-sawab (benar). ${ }^{26}$

Dalam lisan al-'Arab kata الخَطَّاُ yaitu suatu kesalahan yang tidak disengaja, sedangkan الخطء bermakna kesalahan yang disengaja, أخطأ يخطئ digunakan untuk menyatakan sebuah kesalahan baik itu disengaja ataupun karena lupa. Kata الخَاطِيُّ mempunyai makna seseorang yang melakukan sesuatu yang tidak selayaknya. Kata khati'ah mempunyai makna zanbun yang disengaja. ${ }^{27}$ Ar-Raghib al-Asfihani, mengartikan kata al-khit'u dengan arti melenceng dari arah yang sebenarnya.

25 Muhammad Fu'ad 'Abd al-Baqi, al-Mu’jam al-Mufahras..., hlm. 288

26 Abu al-Husain Ahmad Ibn Faris Zakariyya, Mu'jam Maqayis alLugah, Juz II, hlm. 450

${ }^{27}$ Ibnu Manzur, Lisan al- 'Arab, Juz V, hlm. 134-135 
Contoh surat Yusuf: 97

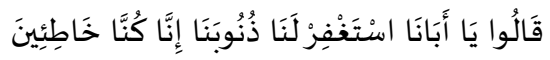

"mereka berkata: "Wahai ayah Kami, mohonkanlah ampun bagi Kami terhadap dosa-dosa Kami, Sesungguhnya Kami adalah orangorang yang bersalah (berdosa)".

\section{Jarmun}

Kata lain yang sangat sering digunakan untuk menyebut istilah dosa di dalam al-Qur'an adalah kata jarmun, sebab kata ini dan turunannya disebutkan sebanyak 66 kali. Dalam lisan al- 'Arab dijelaskan bahwa الجَرْم itu artinya memotong. Kata ini juga bermakna جنى atau (memperoleh). Sedangkan ar-Ragib alAsfihani dalam Mu'jam Mufradat Alfaz al-Qur'an menyatakan bahwa hampir sama, makna asal kata tersebut adalah memotong sesuatu yang seharusnya masih bersambung. Pemotongan ini merupakan suatu pelanggaran atau perbuatan dosa. Dari sini dapat dimengerti bahwa bahasa yang menggunakan kata jarama mempunyai arti untuk segala macam pekerjaan yang tidak baik. Dengan begitu, kata mujrim diartikan dengan yang berdosa atau yang berbuat kesalahan. ${ }^{28}$

Kemudian Ibnu Manzur dalam lisan al-'Arab menjelaskan bahwa kata الجُرمُ bermakna التعدى (menganiaya) dan perbuatan ini termasuk الذنب (dosa), sehingga terkadang jarmun itu bisa bermakna zanbun. Kata ajrama bermakna melakukan tindak kriminal (jinayah). Sedangkan kata الجِرَمُ bermakna jasad (tubuh). Dan kata جَرَمُ digunakan untuk menyebutkan besarnya dosa. ${ }^{29}$

Contoh surat al-An'am: 124

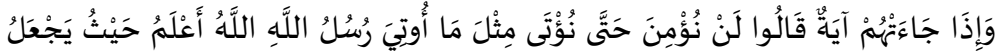

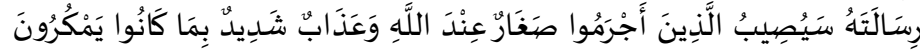

"Apabila datang sesuatu ayat kepada mereka, mereka berkata: "Kami tidak akan beriman sehingga diberikan kepada Kami yang serupa dengan apa yang telah diberikan kepada ut usan-utusan Allah". Allah lebih mengetahui di mana Dia menempatkan tugas kerasulan. orang-

\footnotetext{
${ }^{28}$ Muhammad Fu'ad 'Abd al-Baqi, al-Mu'jam al-Mufahras, hlm. 89

${ }^{29}$ Ibn Manzur, Lisan al- 'Arab, hlm. 128
} 
orang yang berdosa, nanti akan ditimpa kehinaan di sisi Allah dan siksa yang keras disebabkan mereka selalu membuat tipu daya."

\section{Zanbun}

Kata ini dengan berbagai derivasinya muncul sebanyak 39 kali dalam al-Qur'an. Dua puluh satu kata berada di dalam surah Makkiyyah dan sisanya lagi 18 kata berada di dalam surah Madaniyyah. Hampir sebagian besar, 28 kata berbentuk jamak (plural) dan sisanya 11 berbentuk mufrad (singular). ${ }^{30}$ Hitunganhitungan tersebut bisa mengisyaratkan: pertama, bahwa kata zanbun sering digunakan oleh al-Qur'an ketika berinteraksi dengan orang-orang Makkah dan kedua, kata zanbun yang seringkali muncul dalam bentuk jamak, menunjukkan bahwa zanbun memiliki jenis perbuatan.

Kata ini (zanbun) tersusun dari tiga huruf, dzal, nun dan ba' memiliki tiga arti pokok, yakni dosa الجُرم akhir sesuatu dan bagian. ${ }^{31}$ Dalam lisan al-'Arab dijelaskan bahwa kata zanbun itu bermakna itsmun, jarmun dan ma'siyah. Kata الذنابى berarti ekor; berarti ekor burung. Ekor binatang biasanya terletak di belakang, dan sangat dekat dengan tempat keluarnya kotoran. Kata ekor menggambarkan sebuah keterbelakangan atau kehinaan. Ungkapan zanab al-Qaum berarti masyarakat terbelakang. Sedangkan kata اذناب الهمور berarti akhir persoalan. Kata الذناب dibaca kasrah dzal-nya bermakna akibat dari segala sesuatu. $^{32}$

Dalam kitab Mu'jam karya 'Abd al-Rauf, bahwa kata zanbun adalah suatu perbuatan yang tidak diperbolehkan oleh syari'at. Asal zanbun adalah menyiksa dengan dosa atas suatu perbuatan, misalnya dikatakan: "anda menyiksa dia ketika dia melakukan dosa", maka penggunaan kata dosa dalam setiap tempat yang sifatnya merusak yang membawa akibat sebagai gambaran bahwa telah melakukan dosa. Oleh karena itu, zanbun dinamai sebagai pengikut dari segala sesuatu yang mendatangkan akibat atau siksa.

${ }^{30}$ Ibn Faris Zakariyya, Mu'jam Maqayis al-Lugah, Juz II, hlm. 339

${ }^{31}$ Ibn Faris Zakariyya, Mu'jam Maqayis. juz II, hlm. 130

${ }^{32}$ Ibnu Manzur, Lisan al- 'Arab, juz III, hlm. 89

33 ‘Abd Ra'uf Al-Misri, Mu'jam al-Qur'an..., juz 1, hlm. 229 
Contoh surat Ar-Rahman: 39

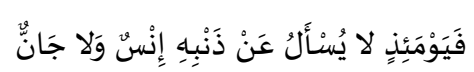

"pada waktu itu manusia dan jin tidak ditanya tentang dosanya".

\section{Junah}

Dengan berbagai istilah tentang kata dosa, Junah adalah salah satu kata lain di dalam al-Qur'an yang diartikan sebagai dosa. Satu makna orisinal adalah الميل (cenderung/berbelok/miring), dan العدوان (permusuhan). Jadi kalau ada kalimat إلى maka

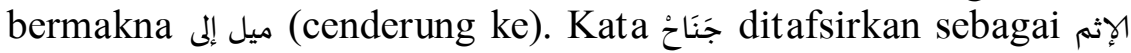
karena berpaling dari yang haq. Sedangkan جَنَاخ adalah bagian dari tubuh burung yakni sayap. Dikatakan janah karena keduanya ولا جناح عليكم (sayap) itu dimiringkan. ${ }^{34}$ Kata junah dalam kalimat dimaknai sebagai al-Jinayah dan al-Jurm. Kalau ada kata la junaha biasanya dimaknai la isma alaikum wa la tudayyiq (tidak ada dosa bagi kalian dan tidak merepotkan). ${ }^{35}$

Ar-Ragib Al-Asfihani memberikan sebuah pernyataan yang sangat menarik dalam ulasan kata ini, yakni bahwa setiap itsmun itu merupakan junah. ${ }^{36}$ Hal senadapun juga diungkapkan oleh 'Abd al-Rauf al-Misri bahwa kata junah di dalam al-Qur'an memiliki banyak makna yang mana di antaranya adalah al-ism, alkharaj, al-mani'(larangan) dan al-tib'ah (akibat/tanggung jawab).

Contoh surat al-Baqarah: 198, 234

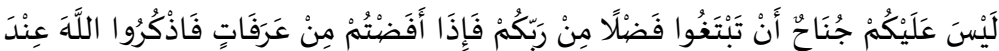

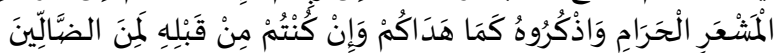

"tidak ada dosa bagimu untuk mencari karunia (rezki hasil perniagaan) dari Tuhanmu. Maka apabila kamu telah bertolak dari 'Arafat, berdzikirlah kepada Allah di Masy'arilharam. Dan berdzikirlah (dengan menyebut) Allah sebagaimana yang ditunjukkan-Nya kepadamu; dan Sesungguhnya kamu sebelum itu benar-benar Termasuk orang-orang yang sesat"

\section{Akibat dan Cara Menghapus Dosa}

\footnotetext{
${ }^{34}$ Ibn Faris Zakariyya, Mu'jam Maqayis..., Juz II, hlm. 208

${ }^{35}$ Ibnu Manzur, Lisan al- 'Arab, Juz II, hlm. 225

${ }^{36}$ Al-Asfihani, Mu'jam Mufradat..., hlm. 98
} 
Menurut Syahminan Zaini bahwa akibat dari berbuat dosa itu ada 17 perkara diantaranya: ${ }^{37}$

1. Merusak hubungan manusia dengan Tuhan

2. Merusak hubungan manusia dan manusia

3. Merusak iman

4. Kesucian manusia yang kotor

5. Merusak kebahagiaan hidup

6. Merusak moral

7. Menjatuhkan martabat manusia

8. Mengundang kemarahan Tuhan

Adapun cara untuk menghapuskan dosa diantaranya:

a. Tobat (al-taubah)

Istilah pertaubatan diartikan sebagai berbalik dan kembali kepada Allah swt. dari dosa seseorang untuk mencari pengampunan. $^{38}$

1. Dzun Nun al-Mishri menegaskan bahwa pertaubatan dibagi menjadi tiga yaitu pertaubatan orang awam (al'amm) yang berarti pertaubatan dari dosanya (taubah min al-zunubi), pertaubatan dari orang yang dipilih (al-khash) berarti pertaubatan dari kelupaan (al-ghaflah), dan pertaubatan para nabi, yang berarti pertaubatan dari kesadaran mereka akan ketidakmampuan untuk mencapai apa yang telah dicapai orang lain. ${ }^{39}$

2. Menurut al-Qusyairi, pertaubatan adalah awal dari kenaikan pertama dan pelayanan bagi para Sufi pemula. Menurutnya pertaubatan adalah kembalinya dari sesuatu yang dikecam oleh syariat terhadap sesuatu yang dipuji oleh syariat. ${ }^{40}$

3. Junaid al-Baghdadi mengatakan bahwa pertaubatan memiliki tiga makna, yaitu penyesalan, tekad untuk

${ }^{37}$ Syahminan Zaini, Problematika Dosa, (Surabaya: Al-Ikhlas, 2001), hlm. 10

${ }^{38}$ John Renard, Historical Dictionary of Sufism (Oxford: the Scarecrow Press, 2005), hlm. 21

39 Al-Kazabi, Ta'aruf li Mazhab, hlm. 93 hlm. 95

${ }^{40}$ Al-Qusyairi, al-Risalah al-Qusyairiyah, (Cairo: Dar al-Ma'arif, t.th), 
meninggalkan semua larangan Allah swt. dan berusaha memenuhi hak-hak semua orang yang telah dirugikan. ${ }^{41}$

b. Wara'

Kata wara' berasal dari bahasa Arab, wara'a, yari'u, wara'an yang berarti hati-hati. Dalam dunia tasawuf, kata wara' ditandai dengan kehati-hatian dan kewaspadaan tinggi. ${ }^{42}$ Wara' menurut pendapat para Sufi adalah sebagai berikut:

1. Al-Qusyairi menjelaskan bahwa wara' harus meninggalkan semua hal yang bersyukur. ${ }^{43}$

2. Ibrahim bin Adam berkata, wara' adalah meninggalkan hal-hal yang tidak berguna. ${ }^{44}$

3. Yahya bin Mu'az berkata, wara' dibagi menjadi dua, wara' lahir, yaitu semua gerakan aktivitas hanya terfokus pada Allah swt. dan wara' batin, yaitu hati yang tidak dimasuki oleh apa pun kecuali hanya mengingat Allah swt. ${ }^{45}$

4. Yunus bin 'Ubaid mengatakan, wara' adalah untuk menghindari semua bentuk syubhat dan untuk melindungi diri dari segala bentuk sudut pandang. ${ }^{46}$

5. Menurut Ibn Qayyim al-Jauziyah, wara' menjaga dirinya dari tindakan dan barang haram dan syubhat. Menurutnya ada tiga derajat wara', yaitu menghindari kejahatan karena mereka ingin melindungi diri, meningkatkan kebaikan dan mempertahankan keimanan; menjaga hukum dalam segala hal yang korup, melepaskan diri dari penghinaan, dan menjaga diri agar tidak melampaui hukum; dan jauhi segala sesuatu yang mengundang perpecahan. ${ }^{47}$

Para sufi yang mengisi hidup dan kehidupan mereka dengan selalu dalam kebersihan dan kemurnian, cantik dalam kebaikan,

${ }^{41}$ Al-Qusyairi, al-Risalah al-Qusyairiyah, hlm. 95

${ }^{42}$ Renard, Historical Dictionary of Sufism, hlm. 199-200

${ }^{43}$ Al-Qusyairi, al-Risalah al-Qusyairiyah, hlm. 110

${ }^{44}$ Al-Qusyairi, al-Risalah al-Qusyairiyah, hlm. 110

${ }^{45}$ Al-Qusyairi, al-Risalah al-Qusyairiyah, hlm. 111

${ }^{46}$ Al-Qusyairi, al-Risalah al-Qusyairiyah, hlm. 112

${ }^{47}$ Ibn Qayyim al-Jauziyah, Madarij al-Salikin, Juz. I, (Cairo: Dar alKutub al-Arabi, 2003), hlm. 445-452 
tentu saja, selalu waspada dalam berprilaku. Sufi tidak mau menggunakan sesuatu yang tidak jelas seperti apa yang najis. Ini dipahami dari hadits Nabi yang menyatakan bahwa setiap makanan yang dilarang untuk dimakan manusia akan menyebabkan noda hitam seiring waktu hati menjadi keras. Ini sangat ditakuti oleh para Sufi yang selalu berharap pada Nur ilahi yang dipancarkan melalui hatinya yang bersih, sikap hidup inilah yang disebut dengan wara '. ${ }^{48}$

\section{E. Interpretasi Ayat-ayat itsmûn}

Kata itsmûn di dalam al-Qur'an disebut sebanyak 48 kali dengan ragam bentuk turunannya. Bentuk kata yang paling sering disebut adalah itsmûn yakni sebanyak 35 kali, sisanya berbetuk آثمين, آثما, أثما, أثيم Tiga puluh tujuh ayat yang memuat kata itsmûn termasuk dalam surah Madaniyyah, sisanya 11 ayat termasuk dalam surah Makkiyyah. ${ }^{49}$ Hal ini menunjukkan bahwa kata itsmûn lebih banyak terjadi di Madinah di mana Islam sudah berkembang dan menghadapi berbagai problem hukum.

Dari sejumlah surat yang menggunakan kata itsmûn yaitu termuat dalam surat al-Baqarah ayat 85, 173, 182, 188, 203, 206, 219, al-Mâidah ayat 2, 3, 62, 63, al-An'am ayat 120, al-A'râf, ayat 33 , an-Nûr ayat 11 , as-Syura ayat 37 , al-Hujarat ayat 12 , an-Najm ayat 32 , al-Mujâdilah ayat 8,9 , ad-Dhukhan ayat 44 , at-Tûr ayat $23 .{ }^{50}$

Contoh-contoh penafsiran

1. Surat al-Baqarah-182

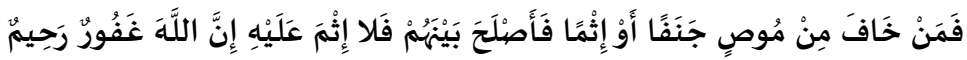

“(akan tetapi) Barangsiapa khawatir terhadap orang yang Berwasiat itu, berlaku berat sebelah atau berbuat dosa, lalu ia (mendamaikan) antara mereka, maka tidaklah ada dosa baginya. Sesungguhnya Allah Maha Pengampun lagi Maha Penyayang”.

48 A. Rivary Siregar, Tasawuf dari Sufisme Klasik ke Neo-Sufisme, (Depok: Rajagrafindo Persada, 1999), hlm. 119

49 ‘Abd al-Baqi, Mu'jam Mufahras..., h. 40-42

50 'Abd al-Baqi, Mu'jam Mufahras..., hlm. 12 
Imam al-Alusi ketika mengartikan kata Itsmun pada ayat tersebut diartikan dengan perbuatan condong berwasiat tanpa ada tujuan (wasiat yang menyimpang) dengan memakai tujuan ada unsur kesengajaan. Itsmun disini yakni di artikan dosa karena satu perbuatan wasiat yang dikatakan dosa apabila orang yang berwasiat kepada orang yang menerima wasiat itu tidak ada yang diwasiatkan (tidak ada tujuan).

Itsmun (itsma) dikatakan tidak ada dosa, apabila wasiat itu yang tadinya jelek atau buruk kemudian di ganti oleh yang menerima wasiat dengan wasiat yang baik, karna Allah swt. selalu menerima wasiat, baik wasiat itu baik atau wasiat itu jelek, namun Allah swt. tidak akan menerima wasiat, apabila wasiat itu ditambah atau di kurang. ${ }^{51}$

Pengertian wasiat menurut Imam al-Alusi yaitu ketika seorang yang akan meninggal dunia kemudian dia berwasiat yang buruk, maka bagi yang menerima wasiat diperbolehkan untuk menggantikan wasiat tersebut menjadi baik. Dengan tujuan agar tidak merugikan antara yang berwasiat dan penerima. Karena Allah swt. selalu menerima wasiat, baik itu wasiat yang berisi keburukan maupun wasiat yang berisi kejelekan.

Pada ayat ini itsmun diartikan sebagai dosa, karena wasiat tersebut bersifat buruk/jelek yang tidak ada faedahnya. Pada ayat tersebut mengandung sebuah perintah untuk memberikan wasiat kepada orang yang ditinggalkan. Untuk memberikan wasiat, hendaknya wasiat itu yang ada faedahnya bukan wasiat yang bersifat jelek yang tidak ada faedahnya. Namun ketika wasiat itu berupa wasiat yang jelek, maka orang yang menerimanya bisa menggantikan wasiat tersebut dengan wasiat yang baik.

Menurut pendapat yang lebih kuat, mengenai pemberian wasiat itu merupakan suatu hal yang bersifat wajib sebelum turunnya ayat yang mengenai mawaris (pembagian harta warisan). Dan ketika turun ayat fara'idh, ayat tentang wasiat itu dinasakh, dan pembagian warisan dengan cara ditentukan menjadi suatu hal yang wajib dari Allah swt. yang memang harus diberikan kepada

51 Al-Alusi, Ruh al-Ma'ani fi Tafsir al-Qur'an al-'Azim wa Sab 'i Mathani, Juz. 2, Jilid. I, (Dar al-Ihya, t.th), hlm. 55 
ahli waris, tanpa perlu adanya wasiat serta tidak mengandung kemurahan dari orang yang berwasiat.

2. Surat al-Mujâdilah- 8

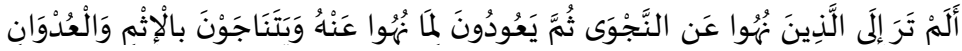

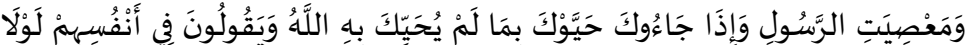

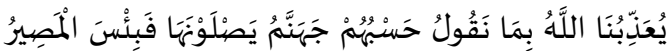

"Apakah tidak kamu perhatikan orang-orang yang telah dilarang mengadakan pembicaraan rahasia, kemudian mereka kembali (mengerjakan) larangan itu dan mereka mengadakan pembicaraan rahasia untuk berbuat dosa, permusuhan dan durhaka kepada rasul. dan apabila mereka datang kepadamu, mereka mengucapkan salam kepadamu dengan memberi salam yang bukan sebagai yang ditentukan Allah untukmu. dan mereka mengatakan kepada diri mereka sendiri: "Mengapa Allah tidak menyiksa kita disebabkan apa yang kita katakan itu?" cukuplah bagi mereka Jahannam yang akan mereka masuki. dan neraka itu adalah seburuk-buruk tempat kembali"

Itsmun disini di tafsirkan oleh imam al-Alusi dengan dosa, karena perbuatan tersebut menimbulkan dosa dan mempunyai akibat terhadap diri mereka sendiri, bertentangan dengan orangorang beriman dan mempunyai sifat maksiat kepada Rasullullah saw. orang-orang munafik saling berwasiat untuk menentang rasul. Adapun menyebutkan maksiat kepada rasul, karena menganggap sangat buruk sekali perbuatan orang-orang munafik dan menganggap sangat besar kemaksiatan mereka. ${ }^{52}$

Kata itsmun dalam ayat tersebut mempunyai makna merugikan bagi diri sendiri dan orang lain, yang mana hal itu mempunyai sifat menentang kepada Rasulullah saw. Yakni yang berkaitan dengan orang lain, dan termasuk dalam pengertian ini ialah perbuatan durhaka kepada Rasul dan menentangnya. Mereka bertekad untuk mengerjakannya dan saling memerintahkan di antara mereka untuk mengulangi perbuatan buruk tersebut (berbisik-bisik). Orang-orang munafik saling berwasiat untuk

${ }^{52}$ Al-Alusi, Ruh al-Ma 'ani, Juz. 28, Jilid. XIV, hlm. 26 
menentang Rasul, berbuat maksiat kepada Rasul yang sangat bertentangan dengan orang mukmin. ${ }^{53}$

Setelah orang-orang Yahudi itu mengucapkan salam yang berupa penghinaan kepada Rasulullah saw. sebagaimana tersebut pada ayat ini, mereka berkata kepada sesamanya "kenapa Allah swt. tidak menimpakan azab kepada kita sebagai akibat jawaban Muhammad. Seandainya Muhammad adalah seorang Nabi dan Rasul yang di utus Allah swt., tentulah kita telah ditimpa azab". Begitulah sangkaan mereka terhadap Allah swt., yaitu bahwa Allah swt. akan mengazab setiap perbuatan orang yang durhaka kepada-Nya. Tetapi ketika azab itu telah datang maka tidak seorangpun yang dapat menghindarkan daripadanya. ${ }^{54}$

3. Surat al-Mujadilah: 9

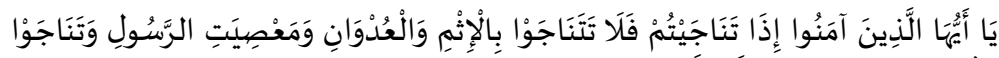

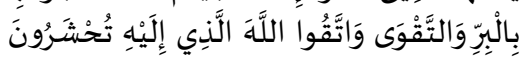

"Hai orang-orang beriman, apabila kamu Mengadakan pembicaraan rahasia, janganlah kamu membicarakan tentang membuat dosa, permusuhan dan berbuat durhaka kepada rasul. dan bicarakanlah tentang membuat kebajikan dan takwa. dan bertakwalah kepada Allah yang kepada-Nya kamu akan dikembalikan."

Kata itśmun disini, imam al-Alusi mengartika sebagai dosa karena dari perbuatan tersebut termasuk perbuatan yang dikerjakan orang-orang munafik, yang selalu menentang terhadap larangan Rasullullah saw. yakni selalu mengulangi perbuatan membicarakan orang lain dengan cara berbisik-bisik. Orang munafik disini adalah orang-orang mukmin/orang beriman selalu mengerjakan shalat tapi di dalam hatinya menentang Rasullullah saw. Dari perbuatannya itu yang mempunyai dampak yang buruk terhadap pelaku. ${ }^{55}$

Ayat tersebut mengandung larangan kepada orang munafik tentang berbicara berbisik-bisik kepada temannya, dikarenakan hal tersebut sangat menyakiti perasaan orang muslim. Perbuatan tersebut sebagaimana yang dilakukan oleh orang-orang yang tidak

${ }^{53}$ Al-Alusi, Ruh al-Ma'ani, Juz. 28, Jiidl. XIV, hlm. 26

54 Qamarudin Shaleh, HAA. Dahlan, M.D. Dahlan, al-Qur'an dan Tafsir Kementrian Agama, Jilid X, (Jakrta: Lentera Abadi, 2010), hlm. 18

${ }^{55}$ Al-Alusi, Ruh al-Ma'ani, Juz. 28, Jilid. XIV, hlm. 27 
mengerti dari kalangan kaum kuffar Ahli Kitab, dan orang-orang yang mengikuti tingkah mereka dalam kesesatannya dari kalangan orang-orang munafik yang selalu menentang Rasul. ${ }^{56}$

4. Surat An-nisâ- 20

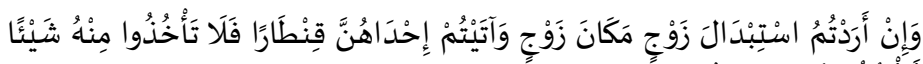

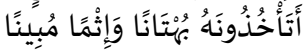

"Dan jika kamu ingin mengganti isterimu dengan isteri yang lain, sedang kamu telah memberikan kepada seseorang di antara mereka harta yang banyak, maka janganlah kamu mengambil kembali dari padanya barang sedikitpun. Apakah kamu akan mengambilnya kembali dengan jalan tuduhan yang dusta dan dengan (menanggung) dosa yang nyata“"

Itsmun pada ayat di atas diartikan oleh imam al-Alusi mempunyai arti kebohongan yang mendatangkan suatu dosa. Karena perbuatan tersebut adalah perbuatan yang merugikan orang lain dengan jalan berbohong, yang mana kebohongan tersebut mengambil maskawin dari istri-istri pertama mereka untuk dipakai sebagai maskawin menikahi orang lain. Maka setiap perbuatan yang merugikan dan merusak orang lain adalah suatu dosa. $^{57}$

Ayat ini mengandung larangan kepada para suami untuk berbuat bohong kepada istri-istrinya dalam hal meminta kembali maskawin yang telah diberikan. Betapa hal itu sangat merugikan orang lain. ${ }^{58}$

Pada ayat ini Allah swt. mengizinkan seorang suami untuk menceraikan istri kalau memang sudah tidak mungkin lagi bersatu. Sekalipun bahwa perbuatan talaq ini adalah sesuatu perkara yang dibenci. Sebagaimana yang terdapat dalam sebuah hadits Nabi saw;

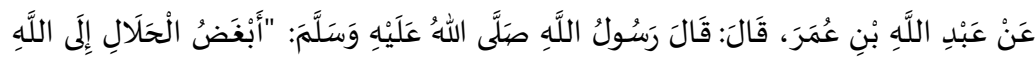
الطُّلَاقُ".

${ }^{56}$ Al-Alusi, Ruh al-Ma 'ani, Juz. 28, Jilid. XIV, hlm. 27

${ }^{57}$ Al-Alusi, Ruh al-Ma 'ani, Juz. 4, Jilid. III, hlm. 244

${ }^{58}$ Al-Alusi, Ruh al-Ma 'ani, Juz. 28. Jilid. XIV, hlm. 27 
"Perkara halal yang dibenci oleh Allah adalah talaq" (H.R. Abu Daud dan Ibn Majjah) 59

yang kemudian diwenangkan untuk menikah lagi. Namun jangan sampai menyakiti perasaan wanita yang dicerai tersebut dengan diantaranya mengambil maskawin yang telah diberikannya. Sebagaimana yang dahulu ketika meminangnya dengan baik, maka saat hendak melepasnya/menceraikannyapun harus dengan memakai cara yang baik. ${ }^{60}$

\section{F. Kesimpulan}

Bersandar kepada imam al-Alûsî yang mempunyai latar belakang tasawuf, peneliti mencoba mengungkap makna itsmun dalam kitab Ruh al-Ma'ani karya beliau. Penelitian tentang kata itsmun dalam al-Qur'an pada penafsiran kajian kitab tafsir Ruh alMa'ani karya al-Alûsî ditemukan berdasarkan data yang ada, dari definisi bahasa ini ditemukanlah cakupan wilayah makna kata itsmun, orang yang banyak dosa, orang kafir, bohong, serta suatu perbuatan yang jauh dari pahala, menghambat datangnya kebaikan (pahala) dan memiliki efek negatif terhadap diri sendiri dan orang lain. Kata itsmun dihubungkan dengan sesuatu yang menggelisahkan hati, serta malu dilihat orang lain.

Kata ini hampir sama penggunaannya dengan zanbun tapi penekanannya lebih pada konteks dosa karena melanggar hal-hal yang sudah diharamkan. Dan hal-hal yang sudah diharamkan ini, berarti sudah ada hukum yang berjalan di masyarakat pada saat itu yaitu di Madinah. Sehingga kata ini cakupannya lebih kecil ketimbang kata zanbun. Meskipun terkadang juga kata itsmun bermakna melawan Allah swt. dan Rasul-Nya, mengingkari ayatayat Allah swt., dan perbuatan yang mendatangkan keburukan, permusuhan, dan menjauhkan dari manfaat, pahala dan kebaikan.

Sedangkan pandangan Imam al-Alusi mengenai solusi terhadap orang yang berbuat dosa, beliau memberikan sebuah cara yaitu, yang pertama dengan bertaubat, kembali kepada jalan Allah

${ }^{59}$ Sunan Abu Daud, Jilid. II, hlm. 255. Dan Sunan Ibn Majah, Jilid. I, hlm. 650

${ }^{60}$ M.D. Dahlan, al-Qur'an dan Tafsir Kementrian Agama, Jilid. II, hlm. 135 
swt. serta tidak mengulangi perbuatan salah, mengakui semua kesalahan-kesalahan yang pernah di perbuat. Yang kedua dengan wara' yaitu harus meninggalkan semua hal yang tidak berguna, menghindari semua bentuk syubhat dan untuk menjaga dirinya dari tindakan dan barang haram.

\section{DAFTAR PUSTAKA}

A. Rivary Siregar, Tasawuf dari Sufisme Klasik ke Neo-Sufisme, (Depok: Rajagrafindo Persada, 1999)

'Abd Rauf Al-Misri, Mu'jam al-Qur'an wahuwa Qamus mufradaat al-Qur'an wa Gharibuhu, ( Kairo: Maktabah alHijazi, 1948)

Abu al-Husain Ahmad Ibn Faris Zakariyya, Mu'jam Maqayis alLugah, Juz. II, (Cairo: Dar al-Hadis, 1998)

Abu Daud Sulaiman bin al-Asy'as al-Sijistani, Sunan Abu Daud, Jilid. II, (Bairut: al-Maktabah al-'Ashriyyah, t.t)

Al-Alusi, Ruh al-Ma'ani fi Tafsir al-Qur'an al-'Azim wa Sab'i Mathani, Juz. 2, Jilid. I, (Dar al-Ihya, t.th)

Al-Qusyairi, al-Risalah al-Qusyairiyah, (Kairo: Dar al-Ma'arif, t.th)

Ali Abdullah Fattah Thabbarah, Dosa Dalam Pandangan Islam, cet. Ke-III, (Bandung: Risalah Gusti, 1986)

Ar-Ragib al-Asfihani, Mu'jam Mufradat Alfad al-Qur'an, (Beirut: Dar al-Fikr, t.th)

AS Hornbay, Oxford Advanced Leavers Dictionary of Current English, (tp: Oxford University Press, 1963)

Badri Khairuman, Sejarah Perkembangan Tafsir Al-Qur'an, (Bandung : CV Pustaka Setia, 2004)

Departemen Agama RI, al-Qur'an dan Terjemahannya, (Depok: Cahaya Qur'an, 2008)

Halimi Zuhdy, Derai Dosa, Derasnya Ampunan Sang Penguasa Semesta (Membincang Dosa dan Pengampunan dalam 
Perspektif Islam), Jurnal, Universitas Islam Negeri (UIN)

Maulana Malik Ibrahim Malang.

Hasbullah Bakry, Pedoman Islam di Indonesia, (Jakarta: UI Press, 1988)

Ibnu Manzur, Lisan al- 'Arab, Juz 1, (Cairo: Dar al-Hadis, 2001)

Ibn Majah Abu 'Abdullah Muhammad bin Yazid al-Quzwainy,

Sunan Ibn Majah, Jilid. I, (Halb: Dar Ihya al-Kutub alArabiyah, t.t)

Ibn Qayyim al-Jauziyah, Madarij al-Salikin, Juz. I, (Cairo: Dar alKutub al-Arabi, 2003)

Imam Al-Ghazali, Rahasia Taubat, terj. Muhammad Baqir, (Bandung: Mizan Media Utama, 2003)

John Renard, Historical Dictionary of Sufism (Oxford: the Scarecrow Press, 2005)

Muhammad 'Ajaj al-Khatib, Ushul al-Hadits, terj, cet. III (Jakarta: Gaya Media Pratama, 2003)

Muhammad Ali ash-Shābuni, Pengantar Studi al-Qur'an (terj), (Bandung: Al-Ma'rif, 1984)

Muhammad Fu'ad 'Abd al-Baqi, al-Mu'jam al-Mufahras li Alfadz Al-qur'an Al-Karim, (Kairo: Dar al-Kutub al-Mishriyah, 1364)

Muhammad Husain al-Dzahabi, Al-Tafsir Wa al-Mufassirun, Juz I. (Dar al-Ma'arif, t. t, 1976)

Muhammad Quraish Shihab, Membumikan Al-Qur'an: Fungsi dan

Peran Wahyu Dalam Kehidupan Masyarakat, (Bandung: Mizan, 1992)

Qamarudin Shaleh, HAA. Dahlan, M.D. Dahlan, al-Qur'an dan Tafsir Kementrian Agama, Jilid X, (Jakrta: Lentera Abadi, 2010)

Syahminan Zaini, Problematika Dosa, (Surabaya: Al-Ikhlas, 2001) Syaikh Manna' al-Qatthan, Pengantar Studi Ilmu Hadits, Mifdhol 'Abdurrahman, terj, (Jakarta: Pustaka al-Kautsar, 2005)

T.M. Hasbi Ash-Shiddieqy, Al-Islam I, (Semarang: PT Pustaka Rizki Putra, 2001)

Tim Penulis, Ensklopedi Islam Indonesia, (Jakarta: Anggota IKAPI, 2002), hlm. 263 